\title{
技術・調查報告 タイ国水資源政策の近沉 \\ Current Status on Water Resources Policy in Thailand
}

\author{
手計 太一1) \\ Patsinghasanee Supapap ${ }^{2)}$ \\ Taichi TEBAKARI
}

\begin{abstract}
1) 富山県立大学工学部
干 939-0398 富山県射水市黒河5180

Department of Environmental and Civil Engineering,

Toyama Prefectural University

Kurokawa 5180, Imizu-shi Toyama 939-0398, Japan
\end{abstract}

2) タイ水資源局

180/3 Soi34, Rama 6 Road, Samsen Nai,

Phaya Thai, Bangkok, Thailand 10400 Department of Water Resources, Thailand

\section{I 。はじめに}

2015 年 5 月, 国家水資源委員会 (National Water Resources Committee*) と水資源マネジメント政策委 員会 (Policy Committee for Water Resources Management) の共同による水資源マネジメント戦略2015-2026 (以降, WRMS) が提出された。本稿では，本戦略 の概要を紹介するとともに, 2016年4月から考案さ れている国家水センター（National Water Center）の 動向について報告する.

\section{II．水資源マネジメント戦略 2015-2026}

WRMS の将来像は,「全ての村々に清潔な水を供 給する, 安全な生産活動, 洪水被害の軽減, 水質管 理の標準化，そして開発と全ての産業部門がバラン スした持続可能な水マネジメント」と謳われている.

WRMS は次の3つの目的が柱となっている。（1） 社会や経済に大きな影響を与える水資源問題の解 決,（2）福祉の改善と水利用のための総合水マネジ メント,（3）持続可能な発展のために河川流域ごと の潜在能力に応じた開発と水利用のバランスを創出 すること。期間については, 現在・緊急（20152016), 近未来 (2017-2021), 将来（2022-2026）の3 時期に分けて計画されている.

水資源マネジメントに影響を与える社会経済要因 として，（1）都市の拡大，（2）世界経済の拡大と夕 イの経済構造の変化, (3) 農業生産, (4) サービ ス・観光部門，（5）気候変動の 5 項目が重要視され ている.また, 自然的要因と行政的な問題として, （1）河川上流域と森林の管理,（2）洪水,（3）利用 可能な水資源の計画, (4) 水質問題, (5) 土壤管理 と土地利用,（6）湿地の管理,（7）水関連部局の縦

割り行政・業務の重複・明解な水政策の不足が挙げ られている。

以上の計画の達成や問題を解決するために, WRMS を6つに分類し戦略計画を立てている.

\section{1. 生活用水のための水マネジメント}

過去 40年間で幾度も（例えば, 1967, 1968, 1977, 1979, 1986, 1987, 1990, 1997, 2002, 2005, 2008）旱魅 に見舞われている。特に全国で影響があったのは， 1979 年, 1997 年, 2008 年の 3 回である. 深刻なレベル から中頻度のリスクのある地域は $4.29 \times 10^{6}$ haある と推定されている。全国で70,372村あるうちの7,490 村では, 適切な水供給システムそのものが整備され ていないのが実情である。

この戦略計画では, 全ての村々, 都市域, さらに 特別経済地区や重要な観光地域に清潔な水を供給す ることが目標になっており, 2021 年までに $100 \%$ 達成 する計画である。 ハード的に水道システムを建設す るだけではなく、節水キャンペーンや水の $3 \mathrm{R}$ 活動 といったソフト対策も含まれている。重要流域とし て, 北部のPing 川流域, 東北部の Khong 川流域, Mun 川流域, Chi川流域が挙げられている (図一1参照).

\section{2. 農業部門と工業部門における水の安全保障の 構築}

農業用水, 生活用水, 工業用水, 観光関連用水を バランス良く最適に配水することが最重要視されて いる。農業用水については, 農業水路に抢ける漏水 を防止し, 灌溉用水の効率を上げる。次に, 正常流 量の確保と生態系のための環境用水を確保すること が重視されている。そして, 農業用水源と工業用水 源の確保が必要とされている。ここで重要視されて 


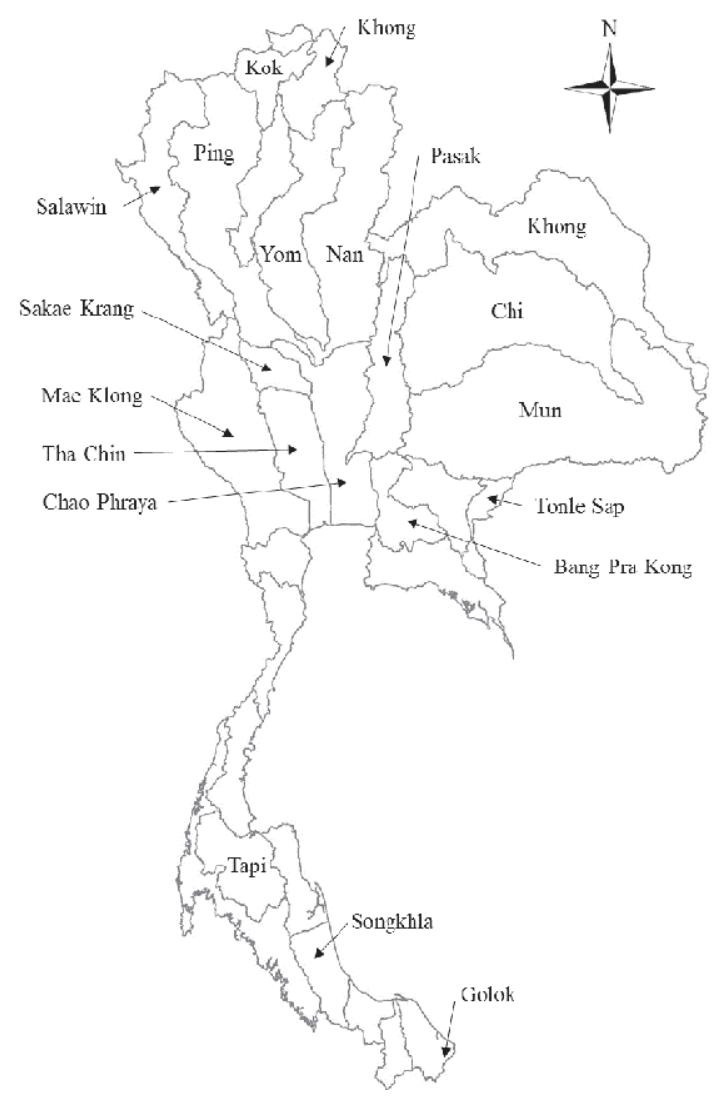

図-1 重要地域に指定されている河川流域

Fig. 1 Criteria river basins.

いる地域は, Yom川, Sakae Krang川, Khong川, Mun 川, Chi川, そして Tongle-Sap川である (図一1参照).

\section{3. 洪水マネジメント}

タイでは, 2005 年, 2006 年, 2010 年, 2011 年を含め て13 回の深刻な洪水に見舞われており，ほぼ全ての 県で被害が発生している。また, 夕イの社会経済を 支えるチャオプラヤー川流域では, 8 回（1975, 1983， 1995, 2002, 2005, 2006, 2010, 2011）の深刻な洪水被 害が発生している。中頻度から高頻度の洪水発生地 域が $1.6 \times 10^{6}$ ha あと推定している。 さらに，斜面 災害リスクのある地域は 6,042 村ある。

このような状況を鑑み, ここでは地域社会や大き な社会経済的影響のある大規模経済圈における洪水 被害の軽減, 農地の被害軽減と洪水被害頻度の高い 地域における適応支援，そして斜面災害と内水汇濫 からの被害の軽減が戦略目標になっている。重要地 域として, Kok川, Chao Phraya 川中流域から下流域, Khong 川流域, Mun川流域, Chi 川流域, Songkhla県
内とマレーシアとの国境付近を流れるGolok川が挙 げられている（図一1参照).

\section{4. 水質管理}

公害管理局 (Department of Pollution Control; DPC) によると, Tha Chin川, Mun川, Songkhla湖流域で は全川で深刻な水質污染が発生している。特に乾期 の環境用水が少ない時期に, 極めて深刻な状況に なっている。 また, 河川への塩水遡上が取水に与え る影響はとても大きく, 生活用水と農業用水のいず れもが大きな問題になっている.

このような状況を解決するために, 水処理システ ムの改善と増設, 点源污染の低減, そして悪化して いる水源の回復によって最大 $80 \%$ の水源の水質を 改善させる計画である。ささらに, 汽水域の塩分量を 生活用水や農業用水の取水水質に適するように管理 する. 下水が問題化している Tha Chin川, Chao Phraya 川, Chi川, Mun川, そして塩水浸入が問題化してい る Tha Chin川, Chao Phraya川, Bang Pra Kong川, Mae Klong川が重要地域に指定されている（図一1参照）.

\section{5. 森林回復と土䁃侵食防止}

北部のNan川流域, Pasak川流域, Salawin川流域 の各上流域において, 夕イで最も深刻な土地利用変 化があった。その次に深刻であったのは，東北部の Mun川流域, Khong川流域, Chi川流域であり，南 部の半島東西の海岸域, Tapi川流域も同様に深刻で あった。このような状況を解決するために次の $2 つ$ の目標が立てられている. (1)上流の森林を修復して 森林の少なくとも $40 \%$ を回復する, (2)表面の土壤 侵食や傾斜農地における斜面崩壊を防ぎ，保水力を 高める。表一1は森林保全と土壤侵食防止・軽減の 数值目標を示している. 上流域の森林の約 $0.8 \times 10^{6}$ ha を保全し, 約 $1.5 \times 10^{6}$ ha を土墰侵食防止・軽減す

表-1 森林保全と土壤侵食防止 - 軽減の数值目標

Table 1 Target of conserve and rehabilitate degrading upstream forests and prevent and reduce soil erosion.

\begin{tabular}{c|c|c|c|c}
\hline \multirow{2}{*}{ 方策 } & \multicolumn{3}{|c|}{ 目標 } & \multirow{2}{*}{ 実施機関 } \\
\cline { 2 - 4 } & $2015-2016$ & $2017-2021$ & $2022-2026$ & \\
\hline 森林保全 & $0.1 \times 10^{6} \mathrm{ha}$ & $0.4 \times 10^{6} \mathrm{ha}$ & $\begin{array}{l}0.25 \times 10^{6} \mathrm{ha} \\
(2024 \text { 年ま }\end{array}$ & RFD, DNP \\
\hline $\begin{array}{c}\text { 圭壤侵食の } \\
\text { 防止・軽減 }\end{array}$ & $0.23 \times 10^{6} \mathrm{ha}$ & $0.64 \times 10^{6} \mathrm{ha}$ & $0.64 \times 10^{6} \mathrm{ha}$ & LDD \\
\hline
\end{tabular}

RFD: Royal Forest Department

DNP: Department of National Parks, Wildlife and Plant Conservation LDD: Land Development Department 
ることとしている

\section{6. 行政管理（データマネジメント）の改善}

政策と運用が一体となっていないことが大きな問 題として提起されている。まず，運用計画や政策決 定に有益なデータがまだ整備途上であり, 包括的な 水マネジメントの法体系が存在していない. そして, 運用システムをモニタリングし，評価する過程が久 けている。 それらを解決に導くために，本戦略の中 では，次の4つの目標が掲げられている.

・水資源マネジメントに関する法律を策定, 単一組 織を設立し，政策と計画の策定を統一する.

・意思決定支援システム (Decision Support System) の中でデータシステムを利用し, 通常時と非常時 の両方の状況において水マネジメントを支援する.

・水資源マネジメント戦略計画を広報して一般に周 知し, 本計画のモニタリングへの市民の参加を促 進する。

・構造物のモニタリング, メンテナンス, 評価する システムを構築する.

\section{III. 国家水センター (National Water Center) の設立に向けて}

2016 年 11 月 23 日の国家水資源委員会 (NWRC) において，国家水センター（夕イ語からの直訳では， 「国家水データセンター」になるが, 英語では” National Water Center”）を実装するために水資源局をホスト にすることが原則的に合意にいたった，本センター は, 国内の水資源に関するデータや情報を一元的に 収集し，政策決定者に適切な情報を提供するセン ターになる予定である。翌年 2017 年 2 月 3 日には, 首相が水資源局を訪問し, 新組織設立に向けて加速 していくことを宣言した。なお，2009年に設立され たHAII（Hydro and Agro Informatics Institute）との大 きな違いは, 研究教育機関と現業機関の違いであり, 国家水センターは後者である.

国家水センターは，智慧の泉（Knowledge Bank）, 数理モデル (Mathematical Model), データバンク（Data Bank), 意思決定支援システム (Decision Support System）の4本柱から業務を行うことになっている. 図一2は国家水センターの構想を示している。本セ

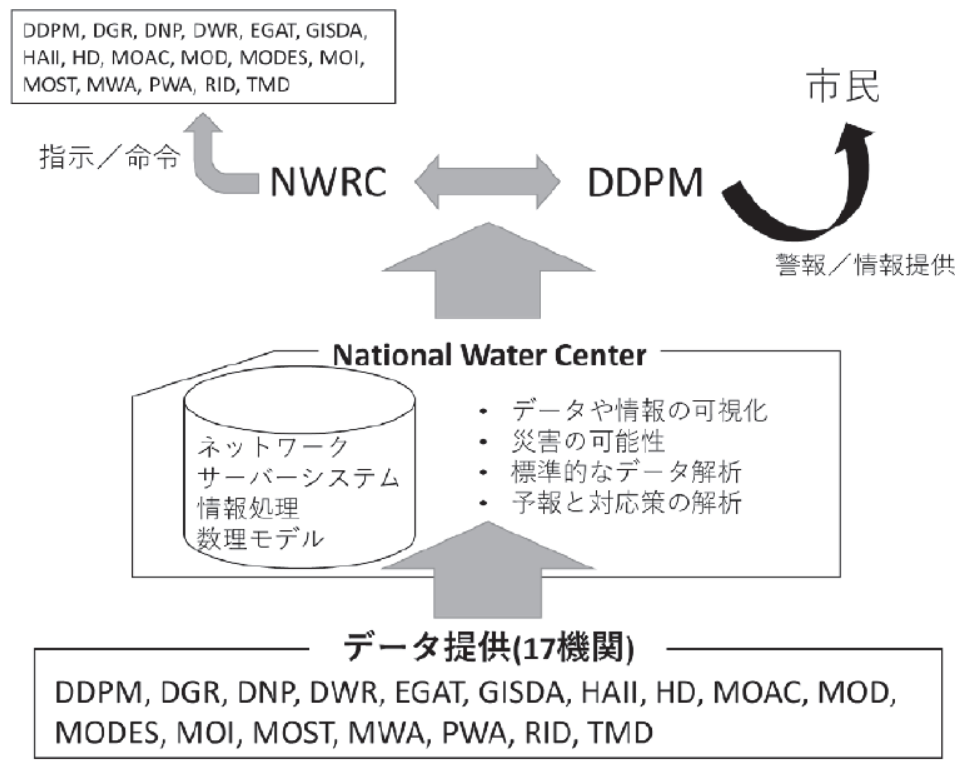

\begin{tabular}{|ll|}
\hline DDPM: Department of Disaster Prevention and Mitigation & MOD: Ministry of Defense \\
DGR: Department of Groundwater Resources & MODES: Ministry of Science and Technology \\
DNP: Department of National Park & MOI: Ministry of Interior \\
DWR: Department of Water Resources & MOST: Ministry of Science and Technology \\
EGAT: Electricity Generating Authority of Thailand & MWA: Metropolitan Waterworks Authority \\
GISDA: Geo-Informatics and Space Technology Development Agency & PWA: Provincial Waterworks Authority \\
HAII: Hydro and Agro Informatics Institute & RID: Royal Irrigation Department \\
HD: Hydrographic Department & TMD: Thai Meteorological Department \\
MOAC: Ministry of Agriculture and Cooperatives & \\
\hline
\end{tabular}

図-2 国家水センターの構想

Fig. 2 Design of National Water Center. 
ンターの最も重要なところは, 水に関連した全部局 からデータや情報を集約し, デー夕統合や情報処理, 数理モデルなどを利用し, 平時・非常時にかかわら ず現業に資するデータや情報を政策決定者に提供す るとともに，DDPM（Department of Disaster Prevention and Mitigation）を通して一般市民に警報や情報提供 するシステムになっている.

\section{IV.おわりに}

今日現在で既に本戦略の 2 年が過ぎているが, 2015 年, 2016 年と旱魅の影響もあり, 短期間の目標を達 した項目は少ないと推察される。しかしながら, 2011 年の大洪水, そしてその後の旱䰠という大きな 両極端の事象を迎え, 中央政府のみならず関連する 全現業機関に危機感が感じられる。本戦略の中には, 水資源マネジメントに関する組織改編や法整備, 一 般への広報，そして本戦略計画を実行するためのガ イドラインや各機関の役割分担も示されており, 実 行可能性が高く，これまでになく期待のできる計画 である.

これらを大きく反映したと言っても過言ではない 国家水センターの設立は，今後のタイの水行政を大
きく飛躍させる可能性がある。本来, HAIIが同様の 役割を期待されていた時期もあるものの, 2011年 チャオプラヤー大洪水や2016年12月・2017年1月 南部洪水に拈いて, 期待されるほどの役割を発揮で きなかった実情があり，その後に，国家水センター 設立が加速している。

2017年4月6日に現国王が新憲法に署名をし，公 布・施行されることとなった，新憲法の下，今後， 統一的な水法の整備, 実施機関の統合などが進むこ とを期待したい.

\section{謝辞}

本調査はJST/JICA SATREPSの支援を受けて実施 されたものである。ここに記して謝意を表す。

*National Water Resources Board と表記する場合もあ るが, 同じ委員会を指す。

\section{引用文献}

The Policy Committee for Water Resources Management. 2015. The Strategic Plan on Thailand's Water Resources Management.

(受付：2017年4月 13 日, 受理：2017年 5 月 24 日) 